\title{
Detection and Variability of Begomoviruses in Tomato from the Andean States of Venezuela
}

A. R. Nava, C. P. Patte, E. Hiebert, and J. E. Polston, Department of Plant Pathology, University of Florida, Gainesville 32611

\begin{abstract}
Nava, A. R., Patte, C. P., Hiebert, E., and Polston, J. E. 2006. Detection and variability of begomoviruses in tomato from the Andean states of Venezuela. Plant Dis. 90:61-66.

The three Andean states of Mérida, Táchira, and Trujillo in Venezuela produce tomatoes (Lycopersicon esculentum) year-round with a high frequency of virus-like symptoms. Polymerase chain reaction amplification using degenerate primers detected begomoviruses in $18 \%$ of leaf samples collected from tomato plants showing virus-like symptoms in commercial fields in these states between 1993 and 1994. A comparison of the sequences of the amplified DNA products revealed a diversity of begomovirus sequences in tomato plants from this region. Partial A component sequences (approximately 1,100 bp) clustered in four groups based on BLAST, GAP, phylogenetic analyses of the nucleic acid sequences, and comparisons of iteron sequences with known begomoviruses. Two groups of sequences were closely related to Potato yellow mosaic virus-Venezuela strain tomato and Tomato Venezuela virus, respectively, begomoviruses previously reported from other Venezuelan states. The other two groups of sequences appear to belong to two new begomovirus species.
\end{abstract}

Additional keyword: geminivirus
Tomato (Lycopersicon esculentum Mill.) is an important crop in Venezuela and is produced commercially in 13 of the 23 states. Tomato production is seasonal in almost all states with the exception of the three Andean states of Mérida, Táchira, and Trujillo. Due to their climatic conditions, these states are able to produce tomatoes year-round and are the primary producers for fresh-market tomatoes when the other states are unable to produce. Additionally, transplants produced in Lara, a major tomato-producing state, are used by growers in Trujillo. Although not as important a region based on size, the Andean states are likely to have a diversity of begomoviruses due to continuous tomato production and importation of transplants from another tomato-producing region.

The presence of at least two begomoviruses has been established in tomato in Venezuela; however, much of what is known is based on a limited number of samples collected from four states. The first report of a whitefly-transmitted virus affecting tomatoes in Venezuela described

Corresponding author: J. E. Polston

E-mail: jep@ufl.edu

Current address of A. R. Nava: Departamento de Agronomía, Facultad de Agronomía, La Universidad del Zulia, A.P. 15205, Maracaibo Venezuela.

Accepted for publication 10 August 2005.

DOI: 10.1094/PD-90-0061
(C) 2006 The American Phytopathological Society
Tomato yellow mosaic virus (ToYMV), the cause of tomato yellow mosaic (9). The symptoms in the affected tomato plants are yellow mosaic, upward cupping and deformation of the leaves, and stunting of the plants. In the state of Aragua in 1963, symptomatic plants were observed at incidences as high as $30 \%$ (9). Symptoms of tomato yellow mosaic were observed in tomato in Aragua and Lara in 1975, and in two additional states, Carabobo and Guarico, by 1978 (1,12). Epidemics of tomato yellow mosaic in tomato in Venezuela have been correlated with large populations of the whitefly, Bemisia tabaci $(2,5,6,8,9)$. Recently, a partial sequence of the genome of ToYMV from a sample collected in Aragua was determined to have $95.7 \%$ nucleotide sequence identity with Potato yellow mosaic virus-Venezuela (PYMV-VE) (14). PYMV-VE was first identified in 1985 as the cause of a yellow mosaic disease of potato in Aragua $(7,8,18,19)$. Thus, it has been proposed that PYMV-VE should not be considered a distinct species, but rather synonymous with ToYMV (14).

Two partial sequences of begomoviruses have been reported from tomato. One from Aragua was considered to be a strain of PYMV-VE (PYMV-VE strain tomato) (11). The other partial sequence was detected in samples collected from the states of Monagas, Guárico, and Portuguesa, and appeared to be from an undescribed virus that was tentatively designated Tomato Venezuela virus (ToVEV) (11).

The objectives of this research were to detect begomovirus sequences in desiccated tomato tissues collected from symptomatic tomato plants in the Andean states of Venezuela, and to analyze their variability.

\section{MATERIALS AND METHODS}

Survey. Samples of leaf tissue from 67 tomato plants showing symptoms of viruslike infection were collected from the main tomato-growing areas of the Andean states (Fig. 1) of Mérida (23 samples), Táchira

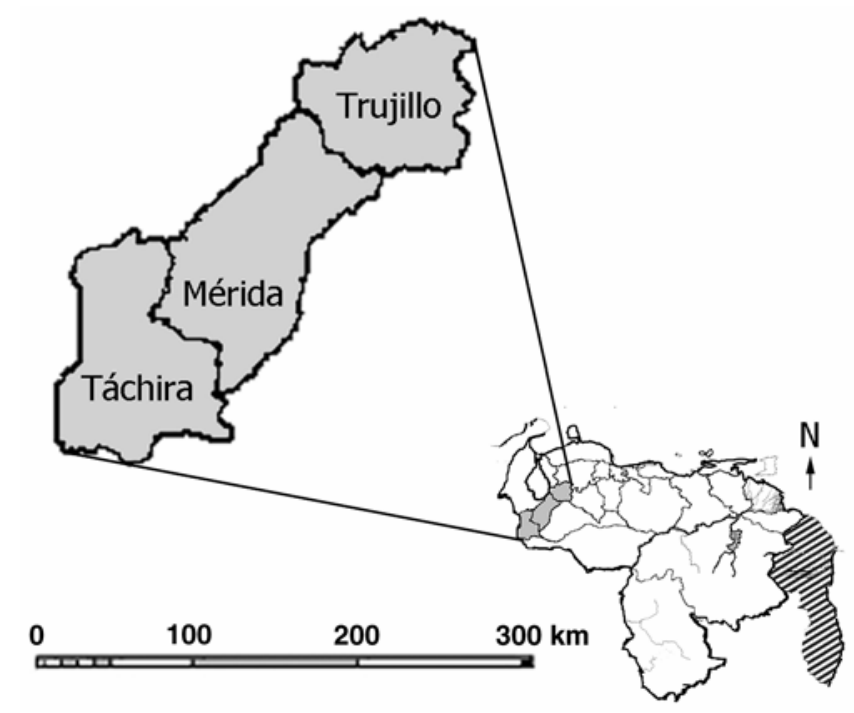

Fig. 1. Map of Venezuela highlighting (in gray) the Andean states of Mérida, Táchira, and Trujillo. Shaded area in eastern Venezuela is disputed territory. 
(26 samples), and Trujillo (18 samples) in Venezuela from 1993 to 1994 (16). In general, mosaic, leaf curl, yellowing, vein clearing, stunting, upward cupping, reduced leaf size, and chlorotic leaf margins were the symptoms observed in the tomato plants. The samples were collected from plants approximately 2 months after transplanting in the field and were dried at room temperature for 2 weeks. Then they were cut, rolled in a piece of tissue paper, stored at $-20^{\circ} \mathrm{C}$.

DNA extraction. Genomic DNA was extracted from each sample a few weeks before amplification using a modification of a protocol developed to obtain tanninand polysaccharide-free genomic DNA from mature plant tissue (17). These modifications included: rehydration of desiccated tissue for $10 \mathrm{~min}$ in $2 \times$ CTAB (cetyltrimethylammonium bromide) buffer before extraction with phenol:chloroform:isoamyl in 25:24:1 ( $\mathrm{vol} / \mathrm{vol} / \mathrm{vol})$ which was used in place of phenol: chloroform in 1:1 (vol/vol). The DNA was stored at $-80^{\circ} \mathrm{C}$.

Polymerase chain reaction (PCR). One set of primers was used for each component of the viral genome. Primers PAR1c496 and PAL1v1978 (20) amplify $\sim 1,100$ bp of the A component. This includes $\sim 690$ bp of the replication associated protein (Rep), $\sim 300$ bp of the common region (CR) between the beginning of the Rep and the beginning of the coat protein $(C P)$, and $\sim 120$ bp of the $C P$. Primers PBL1v2040 and PCRc154 (20) amplify $\sim 700 \mathrm{bp}$ of the B component, which conplaced into a vial containing silica gel, and

sists of part of the nuclear shuttle protein $(N S P)(\sim 160 \mathrm{bp})$, the entire hypervariable region, and most of the $\mathrm{CR}$. The PCR reactions for primer pairs (A primers) PAR1c496 and PAL1v1978 and (B primers) PBL1v2040 and PCRc154 were conducted as described previously (20). The PCR reactions were conducted in a Gene Amp PCR system 9700 (PE Applied Biosystems, Foster City, CA) thermocycler. PCR products were electrophoresed $(1 \mathrm{~h}$ at 90 volts) in $1 \%$ agarose gels in Trisacetate-EDTA buffer, pH 8. Gels were stained with ethidium bromide $(0.0015$ $\mathrm{mg} / \mathrm{ml}$ ) and viewed with a UV transilluminator.

Enzyme restriction of purified PCR products. The PCR products were purified from agarose gels using the QIAquick gel extraction kit (QIAGEN Inc., Valencia, CA). The purified PCR products generated from primer set PAR1c496 and PAL1v1978 were digested with BglII, EcoRI, NcoI, and NdeI, and PCR products generated from primer set PBL1v2040 and PCRc154 were digested with EcoRI, HindIII, KpnI, NdeI, and XbaI. Digestion conditions were performed according to the manufacturer's instructions (New England Biolabs, Inc., Beverly, MA).

Cloning and DNA sequence determination. Ligation of purified PCR products amplified from Andean samples was performed using the pGEM-T Easy vector system I (Promega Corporation, Madison, WI) according to the manufacturer's instructions. Transfection was performed using XL1-Blue MRF Supercompetent Escherichia coli cells (Stratagene, La Jolla,

Table 1. Acronyms and accession numbers of begomovirus sequences used in the analyses of DNA sequences amplified from tomato samples from the Andean states of Venezuela

\begin{tabular}{lll}
\hline Species & Acronym & Accession number \\
\hline Bean dwarf mosaic virus & BDMV & M88179 \\
Bean golden yellow mosaic virus-[Puerto Rico] & BGMV-[PR] & M10080 \\
Chino del tomate virus & CdTV & AF226664 \\
Chino del tomate virus-[IC] & CdTV-[IC] & AF101476 \\
Dicliptera yellow mottle virus & DiYMoV & AF170101 \\
Jatropha mosaic virus & JMV & AF324410 \\
Macroptilium golden mosaic virus-[Jamaica] & MGMV-[JM] & AF098940 \\
Macroptilium yellow mosaic Florida virus & MaYMFV & AY044136 \\
Potato yellow mosaic Panama virus & PYMPV & Y15033 \\
Potato yellow mosaic virus -[Guadeloupe] & PYMV-[GP] & AY120882, Y120883 \\
Potato yellow mosaic virus-[GP] from Dominican & PYMV-[GP] & AY126611, AY126614 \\
Republic & & \\
Potato yellow mosaic virus-[GP] from Martinique & PYMV-[GP] & AY126610, AY126612 \\
Potato yellow mosaic Trinidad virus-Trinidad \& & PYMTV-TT & AF039031, AF039032 \\
Tobago & & \\
Potato yellow mosaic virus -Venezuela & PYMV-VE & D00940, D00941 \\
Potato yellow mosaic virus -Venezuela strain tomato & PYMV-VE-[tom] & AF026553 \\
Rhynchosia golden mosaic virus & RhGMV & AF239671 \\
Sida golden mosaic Costa Rica virus & SiGMCRV & X99550, X99551 \\
Sida golden mosaic Honduras virus & SiGMHV & Y11097 \\
Tomato dwarf leaf curl virus & ToDLCuV & AF035225 \\
Tomato golden mottle virus & ToGMoV & AF138298 \\
Tomato leaf curl Malaysia virus & ToLCMV & AF327436 \\
Tomato leaf curl Sinaloa virus & ToLCSinV & AF131213 \\
Tomato mottle Taino virus & ToMoTV & AF012300, AF012301 \\
Tomato mottle virus [Florida] & ToMoV-[FL] & L14461 \\
Tomato Venezuela virus & ToVEV & AF026464 \\
Tomato yellow leaf curl virus-[Florida] & TYLCV-[FL] & AY530931 \\
\hline
\end{tabular}

CA). The clones were screened with the same restriction enzymes used above. The nucleotide sequence of cloned PCR products was determined by automated sequence analysis at the DNA Sequencing Core Laboratory, Interdisciplinary Center for Biotechnology Research (ICBR), University of Florida, Gainesville.

Comparison of DNA sequences. $\mathrm{Nu}$ cleic acid sequences were analyzed using the Wisconsin Package Version 10.3, (Accelrys [GCG], San Diego, CA). Basic Local Alignment Search Tool (BLAST) was used to search for similarities between a query sequence and all the sequences in the database. The six begomovirus sequences from the database that had the highest homology value to each Andean sequence were selected for analysis using GAP to compare nucleotide sequence identities (NSI). Multiple alignments of Andean sequences and the begomovirus sequences (selected by the highest NSI values) were performed using PILEUP.

Phylogenetic analysis. Phylogenetic analysis was carried out using PAUP (Phylogenetic Analysis Using Parsimony). A maximum parsimony and heuristic tree search were used to generate the best tree. The initial tree was created by stepwise addition with tree-bisectionreconnection as the branch swapping method. The reliability of the tree was estimated by performing 500 bootstrap repetitions. The begomoviruses selected for the phylogenetic analysis are listed in Table 1. Selection was based on the highest NSI values.

\section{RESULTS}

PCR amplification of begomovirus sequences from field samples. Approximately $18 \%(12 / 67)$ of the samples collected from the three Andean states produced a PCR product of $\sim 1,100$ bp using the degenerate A primers and $16 \%(11 / 67)$ of the samples produced a PCR product of $\sim 700 \mathrm{bp}$ using the degenerate B primers (Table 2). DNA from the 12 samples amplified by A component primers were selected for further analysis.

Restriction enzyme analysis of purified PCR product. Restriction patterns of PCR products amplified with A primers were compared with those expected of the same region of selected begomoviruses which are known to infect tomato (Tomato yellow leaf curl virus-[Florida], Tomato Venezuela virus, Tomato mottle virus[Florida], Tobacco leaf curl virus, Sida golden mosaic virus, Potato yellow mosaic virus-Venezuela [strain tomato], Potato yellow mosaic virus-Venezuela, Potato yellow mosaic Trinidad virus-Trinidad \& Tobago, Potato yellow mosaic virus[Guadeloupe], Pepper huasteco yellow vein virus). None of the 12 samples produced restriction-fragment sizes identical to the selected begomoviruses (Table 3). However, the restriction-fragment sizes of 
each sample were useful to distinguish the presence of single or mixed infections in each sample. Five samples appeared to be infected with multiple begomoviruses, 2.2v, 2.4-v, 8-v, 10-v, and 82-v (Table 3). Two (10-v and 82-v) were later confirmed as mixed infections by sequence analysis of cloned PCR products (Table 4).
There were fewer differences in restriction patterns among amplified products using the B primers. This could be due in part to the shorter length of the PCR product used for this analysis, and to the fact that this region appears to have few restriction sites. XbaI had no restriction sites in any of the samples, HindIII had one re- striction site in one sample, and NdeI and $E c o$ RI had one restriction site in three and six of 11 samples, respectively (data not shown). The restriction analysis of the $\mathrm{B}$ component PCR products did not distinguish presumed $\mathrm{B}$ components in mixed infections, unlike the analysis of A component PCR products.

Table 2. Detection of begomovirus sequences using polymerase chain reaction (PCR) and two sets of primers in samples of tomato plants with virus-like symptoms collected from production fields in Andean states of Venezuela

\begin{tabular}{lcccccc}
\hline & & & & \multicolumn{2}{c}{ No. positive by PCR (\% positive of total) } \\
\cline { 5 - 7 } State & No. locations & No. fields & No. samples & Year collected & PAR1c496/PAL1v1978 & PBL1v2040/PCRc154 \\
\hline Mérida & 6 & 11 & 23 & 1994 & $3(13 \%)$ & $2(9 \%)$ \\
Táchira & 7 & 10 & 26 & 1993 & $1(4 \%)$ & $1(4 \%)$ \\
Trujillo & 6 & 6 & 18 & 1993 & $8(42 \%)$ & $8(42 \%)$ \\
Total & 19 & 27 & 67 & & $12(18 \%)$ & $11(16 \%)$ \\
\hline
\end{tabular}

Table 3. Restriction-fragment sizes in the polymerase chain reaction products amplified by an A component primer set (PAR1c496/PAL1v1978) from tomato samples collected in the Andean states of Venezuela

\begin{tabular}{|c|c|c|c|c|c|}
\hline \multicolumn{2}{|l|}{ Source of DNA } & \multicolumn{4}{|c|}{ Restriction enzyme fragment sizes (bp) } \\
\hline State & Sample & BglII & EcoRI & NcoI & NdeI \\
\hline Trujillo & $2.2-\mathrm{v}$ & $600+600$ & 1150 & $1000+160+116$ & $1150+950+850+175+134$ \\
\hline Trujillo & 6-v & $600+600$ & 1150 & $900+160+116$ & 1150 \\
\hline Trujillo & $2.4-\mathrm{v}$ & $600+350$ & $1150+750++350$ & $1000+900+160+116$ & $1150+1000+850+750+300+134$ \\
\hline Trujillo & $2.7-\mathrm{v}$ & $800+350$ & 1150 & $900+160+108$ & 1150 \\
\hline Trujillo & $2.8-\mathrm{v}$ & $800+350$ & 1150 & $900+160+108$ & 1150 \\
\hline Trujillo & $2.9-\mathrm{v}$ & $800+350$ & 1200 & $900+160+108$ & 1150 \\
\hline Trujillo & $8-v$ & $600+350+250$ & 1200 & $1100+116$ & $1150+900+800+350$ \\
\hline Trujillo & $10-\mathrm{v}$ & $600+350+250$ & $750+350$ & $1100+900+200+161+130$ & $1150+900+300$ \\
\hline Tachira & $28-\mathrm{v}$ & $600+600$ & 1200 & $900+185+130$ & $1150+182$ \\
\hline Mérida & $56-\mathrm{v}$ & $800+350$ & $750+350$ & $1000+185$ & $1150+182$ \\
\hline Mérida & $57-\mathrm{v}$ & $800+350$ & $750+350$ & $1000+185$ & 1150 \\
\hline Mérida & $82-\mathrm{v}$ & $800+350$ & $800+370$ & $1000+900+185+130$ & $900+300+182$ \\
\hline TYLCV-FL & $-a$ & $-\mathrm{b}$ & $760+531$ & $1234+57$ & $1000+291$ \\
\hline ToVEV & $-\mathrm{a}$ & $566+329+227$ & $781+341$ & $762+253+107$ & $829+293$ \\
\hline ToMoV-[FL] & $-a^{a}$ & $808+330$ & - & $1031+107$ & $844+294$ \\
\hline TLCV & $-a$ & - & $944+345$ & - & - \\
\hline SiGMV & $-a$ & $810+330$ & - & $667+317+156$ & $846+294$ \\
\hline PYMV-VE- [tom] & $-\mathrm{a}$ & - & - & $1021+107$ & $753+375$ \\
\hline PYMV-VE & $-a$ & - & - & $1023+107$ & - \\
\hline PYMTV-TT & $-\mathrm{a}$ & - & - & - & - \\
\hline PYMV-[GP] & $-\mathrm{a}$ & $602+556$ & - & $1025+134$ & - \\
\hline PHYVV & $-a^{a}$ & $837+327$ & $819+345$ & - & $873+291$ \\
\hline
\end{tabular}

a Fragment sizes are predicted sizes based on sequences published in GenBank.

$\mathrm{b}$-: indicates no restriction site predicted from published sequence.

Table 4. Comparison of nucleotide sequence identity (\%) among partial sequences from polymerase chain reaction products amplified using A component primer set for begomoviruses from Andean states and four known begomoviruses

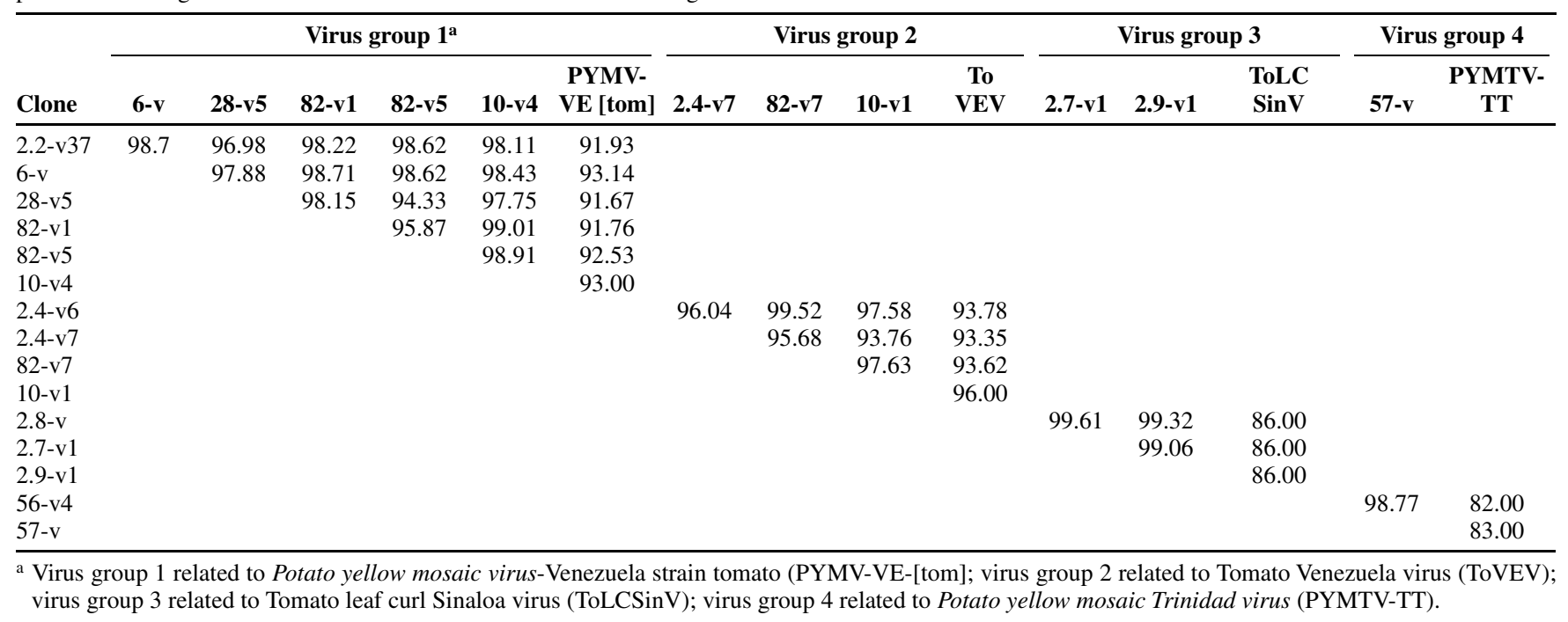


DNA sequence comparison. Fifteen clones of PCR products amplified by A primers from 12 samples were submitted for a BLAST search. These 1,100 -bp sequences clustered into four groups by GAP analysis based on the greatest percentage of nucleotide sequence analysis (NSI) with a known begomovirus (Table 4). The percent NSI ranged from 94.3 to $99 \%$ among the six sequences in group 1 , from 93.8 to $99.5 \%$ among the four sequences in group 2, from 99.1 to $99.6 \%$ among the three sequences in group 3 , and was $98.8 \%$ between the two sequences in group 4 (Table 4). Group 1 sequences had the greatest percent NSI with PYMV-VE[tom] (92 to 93\%), group 2 sequences with ToVEV (93 to 96\%), group 3 sequences with Tomato leaf curl Sinaloa virus (ToLCSinV) (86\%), and group 4 sequences with PYMTV-TT (82 and $83 \%$ ). Sequences in groups 3 and 4 had the lowest percentage of NSI with known begomoviruses of all the groups and were therefore considered sequences of potentially new begomovirus species.

Sequences belonging to group 1 (related to PYMV-VE-[tom]) were detected in samples from all three Andean states. Sequences belonging to group 2 (related to ToVEV) were detected in samples from Mérida and Trujillo. All the sequences belonging to group 3 were detected in samples from one state (Trujillo), and all the sequences belonging to group 4 were detected in samples from one state (Mérida).

The 15 partial A component sequences had a conserved nonameric motif $5^{\prime}$ TAATATTAC $3^{\prime}$ in the intergenic region, located in the loop of the conserved "hairpin" element, where Rep introduces a sitespecific nick to initiate virus replication via a rolling-circle mechanism (13). Two inverted repeats, two forward repeats, and a TATA box were present downstream of the stem loop sequence in all the sequences in group 1; the sequences in the other groups showed differences in the number of inverted and forward repeats. These inverted repeats or interactive sequences (referred to as iterons) have been reported to be specific binding sites for the Rep (Rep iteron-related domain), to initiate the rolling circle replication process, and have been found to be useful in taxonomic comparisons $(3,4)$.

Begomoviruses clustered in group 1 share the iteron core sequence, GGGGG, and the GSFSIK Rep iteron-related domain with PYMV (Table 5). The core sequences of the iterons and Rep iteron-related domain of sequences in group 2 were similar to those of ToVEV. There was a nucleotide change resulting in a different amino acid in the Rep iteron-related domain between sequences of group 2 and ToVEV (lysine for isoleucine due to substitution of $\mathrm{A}$ for $\mathrm{T}$ in the nucleic acid sequence). The iteron and Rep iteron-related domain sequences of ToVEV were reported as unique, not closely resembling those of other bego-

Table 5. Motifs of the intergenic region and iteron-related domain of replication protein (Rep IRD) of cloned sequences from Andean states and selected begomoviruses

\begin{tabular}{|c|c|c|c|c|c|c|}
\hline Group & Sequence $^{\mathrm{a}}$ & Invert repeat & Invert repeat & Forward repeat & Forward repeat & Rep IRD \\
\hline 1 & $2.2-\mathrm{v} 37$ & CCCCCGATA & СССССААТТ & ААТТ $G G G G G$ & ААCТ $G G G G G$ & MPRKGSFSIK \\
\hline 1 & $6-v$ & CCCCCGATA & СССССААТТ & ААТТ $G G G G G$ & ААCТ $G G G G G$ & MPRKGSFSIK \\
\hline 1 & $10-\mathrm{v} 4$ & CCCCCGATA & СССССААТТ & ААТТ $G G G G G$ & АACT $G G G G G$ & MPRKGSFSIK \\
\hline 1 & $28-\mathrm{v} 5$ & CCCCCGATA & СССССААТТ & ААТT $G G G G G$ & ААCТ $G G G G G$ & MPRKGSFSIK \\
\hline 1 & $82-\mathrm{v} 1$ & CCCCCGATA & СССССААТТ & ААТT $G G G G G$ & АACT $G G G G G$ & MPRKGSFSIK \\
\hline \multirow[t]{6}{*}{1} & 82 -v5 & CCCCCGATA & СССССААТТ & ААТТ $G G G G G$ & ААCТ $G G G G G$ & MPRKGSFSIK \\
\hline & PYMV-Mart & СССССААТА & СССССАATA & ААTT $G G G G G$ & $\mathrm{AACT} G G G G G$ & MPRKGSFSIK \\
\hline & PYMV-[GP] & СССССААТА & СССССААТА & ААТТ $G G G G G$ & ААCТ $G G G G G$ & MPRKGSFSIK \\
\hline & PYMV-[DR] & СССССААТА & СССССАAТА & ААТT $G G G G G$ & ААСТ $G G G G G$ & MPRKGSFSIK \\
\hline & PYMV-Tom & СССССААТА & СССССААТТ & ААТТ $G G G G G$ & ААCТ $G G G G G$ & MPRKGSFSIK \\
\hline & PYMV-VE & СТСССААТА & СССССТАТТ & ААТT $G G G G G$ & ААCТ $G G G G G$ & MPRKGSFSIK \\
\hline 2 & $10-\mathrm{v} 1$ & & TGCACCGATT & AATTGGGGCA & AATTGGGGTC & MPPPKHFRLN \\
\hline 2 & $2.4-\mathrm{v} 6$ & & TGCACCGATT & AATTGGGGCA & AATTGGGGTC & MPPPKHFRLN \\
\hline 2 & $2.4-\mathrm{v} 7$ & & TGCACCGATT & AATTGGGGCA & AATTGGGGTC & MPPPKHFRLN \\
\hline \multirow[t]{2}{*}{2} & $82-\mathrm{v} 7$ & & TGCACCGATT & AATTGGGGCA & AATTGGGGTC & MPPPKHFRLN \\
\hline & ToVeV & & TGCACCGATT & AATTGGGGCA & AAATGGGGTC & MPPPKHFRIN \\
\hline 3 & $2.7-\mathrm{v} 1$ & & СССССААТТ & ААТC $G G G G G$ & ААCT $G G G G G$ & MPRKGSFSIK \\
\hline 3 & $2.8-\mathrm{v}$ & & СССССААТТ & AАТC $G G G G G$ & ААСТ $G G G G G$ & MPRKGSFSIK \\
\hline 3 & $2.9-\mathrm{v} 1$ & & СССССААТT & AATC $G G G G G$ & AАCT $G G G G G$ & MPRKGSFSIK \\
\hline 4 & $56-\mathrm{v} 4$ & & ACACCAATT & АATC $G G T G \mathrm{~T}$ & & MPTARAFKIN \\
\hline \multirow[t]{2}{*}{4} & $57-v$ & & ACACCAATT & AАTC $G G T G \mathrm{~T}$ & & MPTARAFKIN \\
\hline & RhGMV & & ACCCCGATT & TATCGGTGT & TATCGGTAT & MPQPRRFRIN \\
\hline
\end{tabular}

a Virus names and accession number are described in Material and Methods. Iteron core and Rep IRD motif are shown in italic.

Table 6. Comparison of nucleotide sequence identity (\%) among partial sequences from polymerase chain reaction products amplified using the B component primer set for begomoviruses from Andean states and four known begomoviruses

\begin{tabular}{|c|c|c|c|c|c|c|c|c|c|c|c|c|}
\hline \multirow[b]{2}{*}{ Clone } & \multicolumn{7}{|c|}{ Virus group $1^{\mathrm{a}}$} & \multicolumn{2}{|c|}{ Virus group 2} & \multirow{2}{*}{$\begin{array}{c}\begin{array}{c}\text { Virus } \\
\text { group } 3\end{array} \\
\text { ToGMoV }\end{array}$} & \multicolumn{2}{|c|}{ Virus group 4} \\
\hline & 2.7-vB3 & 6-vB2 & 2.2-vB6 & 8-vB12 & 10-vB15 & 28-vB2 & PYMV-VE & 2.4-vB24 & ToMoTV & & 57-vB2 & DiYMoV \\
\hline 2.4-vB34 & 99.01 & 95.37 & 92.00 & 91.43 & 91.91 & 91.22 & 94.00 & & & & & \\
\hline 2.7-vB3 & & 95.04 & 91.90 & 90.92 & 91.58 & 90.89 & 93.00 & & & & & \\
\hline 6-vB2 & & & 94.00 & 91.90 & 93.21 & 92.88 & 92.00 & & & & & \\
\hline 2.2-vB6 & & & & 88.00 & 95.10 & 92.10 & 92.00 & & & & & \\
\hline 8-vB12 & & & & & 87.56 & 87.33 & 93.00 & & & & & \\
\hline $10-\mathrm{vB} 15$ & & & & & & 93.20 & 95.00 & & & & & \\
\hline 28-vB2 & & & & & & & 97.00 & & & & & \\
\hline 2.8-vB8 & & & & & & & & 94.86 & 86.00 & & & \\
\hline 2.4-vB24 & & & & & & & & & 86.00 & & & \\
\hline 2.9-vB20 & & & & & & & & & & 86.00 & & \\
\hline 56-vB7 & & & & & & & & & & & 96.55 & 86.00 \\
\hline $57-\mathrm{vB} 2$ & & & & & & & & & & & & 86.00 \\
\hline
\end{tabular}


moviruses from the New World (4). Sequences in group 3 also shared the iteron core sequence, GGGGG, and the GSFSIK Rep iteron-related domain with PYMV. However, unlike PYMV, which has two inverted and forward repeats, the sequences in group 3 have only one inverted repeat (Table 5). This major difference implies that the sequences in group 3 are unique. The sequences in group 4 are distinctive, since they have one inverted and one forward repeat, and the iterons are different from but most similar to those of RhGMV (Table 5).

Partial sequences amplified from the B component clustered into four groups based on the BLAST search and GAP analysis (Table 6). Sequences 2.2-vB6, 2.4-vB34, 2.7-vB3, 6-vB2, 8-vB12, 10vB15, and 28-vB2 had high percentages of NSI (92 to 95\%) with PYMV-VE. The value of NSI within this group ranged from 87 to $99 \%$. These begomoviruses may be strains of PYMV-VE, but further studies would have to be done to confirm this assumption. It is possible that most of these samples could be separated into two groups based on the comparison of the A component sequences, except for the complication that $\mathrm{B}$ component sequences have not been reported for PYMV-VE-[tom] and ToVEV (Table 4). Therefore, the B component sequences for these samples clustered with PYMV-VE. The sequences, 2.8-vB8 and 2.4-vB24, had a moderate percent NSI (86 and $88 \%$, respectively) with ToMoTV. The sequence 2.9-vB20 had $86 \%$ NSI with ToGMoV, and the sequences 56-vB7 and 57-vB2 had moderate percentages of NSI $(86 \%)$ with DiYMoV (Table 6).

Phylogenetic analysis. A phylogenetic tree based on the nucleic acid sequences of clones generated by amplifications using A component primers was generated (Fig. 2). The Andean sequences followed the same tendency of clustering that was observed in the GAP analysis. Sequences 2.2-v37, 6-v, 28-v5, 10-v4, 82-v1, and 82-v5 are closely related to the PYMV virus group. Even though this analysis was done with partial sequences, it is possible to infer that PYMV-VE strain tomato is distributed in the three Andean states. These data also confirm that MGMV is a sister taxon of the clone group mentioned above. The sequences 10-v1, 2.4-v6, 2.4-v7, and 82-v7 are closely related to ToVEV.

RhGMV and ToLCMV are sister taxa to sequences 57-v and 56-v4, and 2.7-v1, 2.8$\mathrm{v}$, and 2.9-v1, respectively. These two groups of sequences clustered by themselves and are not closely related to other known begomovirus.

The begomovirus sequences amplified by $\mathrm{B}$ primers clustered into 3 groups using phylogenetic analysis (Fig. 3). Most of the B component sequences (28-vB2, 2.2-vB6, 10-vB15, 6-vB2, 8-vB12, 2.4-vB34, and 2.7-vB3) were closely related to strains and isolates of PYMV-VE. The B component sequences 2.8-vB8, 2.9-vB20, and 2.4-vB24 were not closely related to any begomovirus sequences available at the time of this analysis. The last group of B component sequences, 56-vB7 and 57$\mathrm{vB2}$, were distantly related to BGYMV[PR] and MaYMFV. The latter two groups appeared to belong those of new begomoviruses.

The partial A and B component sequences from the same sample did not always cluster with the same sequences in the two phylogenetic trees. For example, sequences from samples $2.4-\mathrm{v}$ and $2.7-\mathrm{v}$ were clustered in different groups for the A and B component trees (Figs. 2 and 3). This is primarily due to the fact that there were four clusters of partial sequences in the A component tree and three in the B

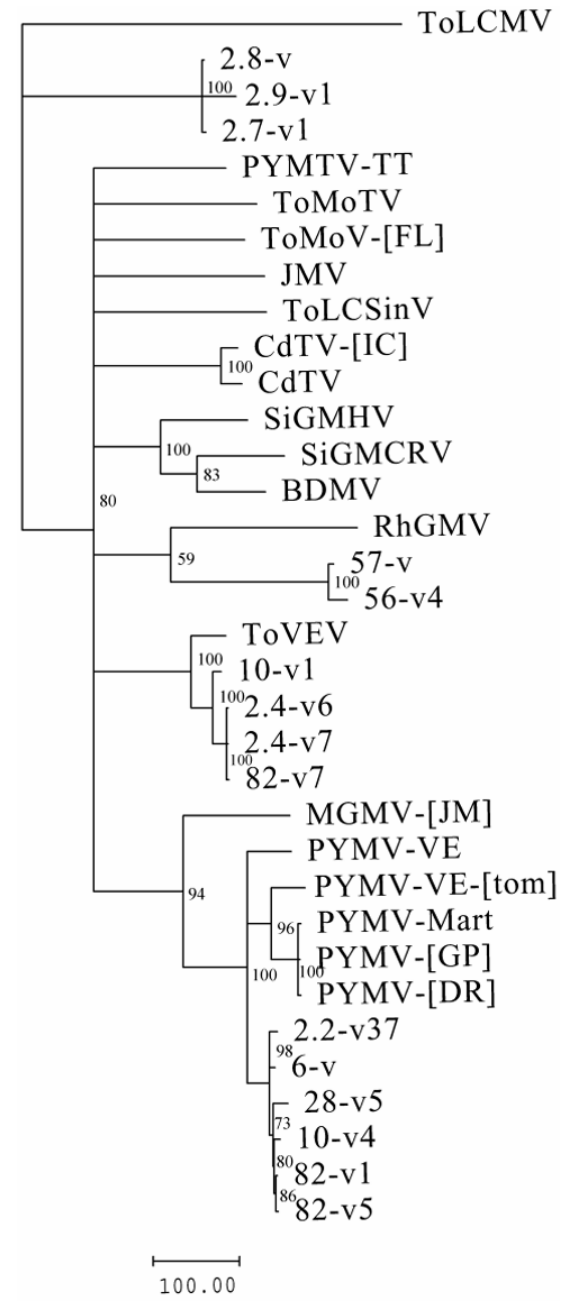

Fig. 2. Phylogenetic tree constructed based on the nucleotide sequences of the polymerase chain reaction products amplified using the primer set PAR1c496/PAL1v1978 for the A component. Tree was generated using PAUP program. A single most parsimonious tree was predicted by a heuristic search with stepwise addition, random branch-swapping, and treebisection-reconnection options (500 replications for bootstrapping). Bootstrap indices are shown at each node. Scale bar references branch length as frequency of changes per site. component tree. This may be a result of the presence of fewer B component sequences in the GenBank database. A greater number of sequences allows for greater precision in phylogenetic analysis.

\section{DISCUSSION}

Begomoviruses were detected in approximately $18 \%$ of samples collected from tomato plants with virus-like symptoms from commercial fields in the three Andean states of Mérida, Táchira, and Trujillo in Venezuela. This is first evidence for the presence of diverse begomoviruses in tomato from these states. Until this study, begomoviruses infecting tomatoes had been reported only from Lara, Aragua, Guárico, Monagas, Portuguesa, and Zulia $(9,11,12,15)$.

There appeared to be at least four distinct begomoviruses in the Andean states. Three types of analyses-GAP, iteron and Rep iteron-related domain comparison, and phylogenetic analysis of partial A component sequences - suggested the presence of

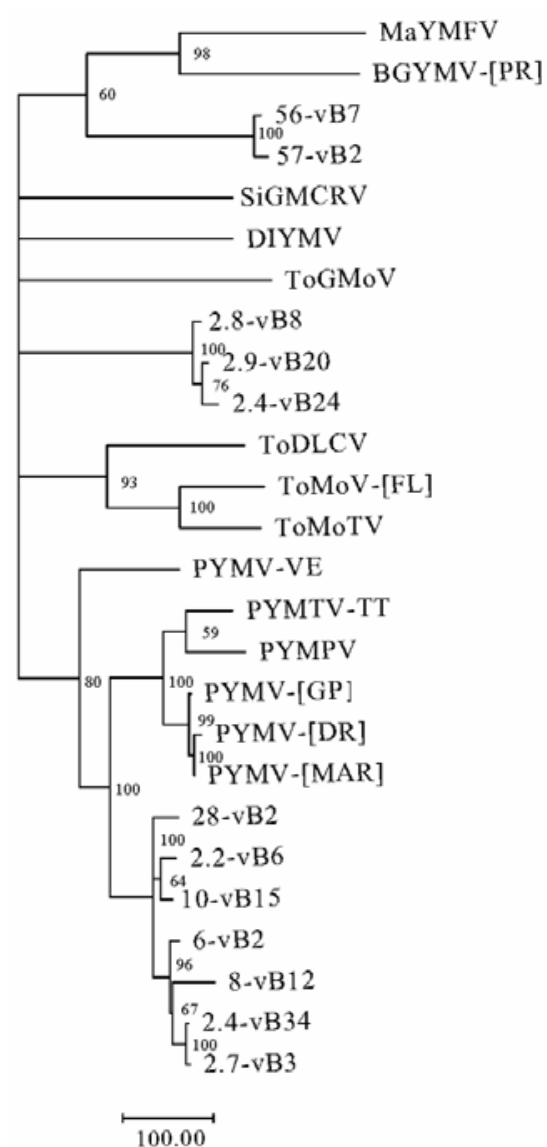

Fig. 3. Phylogenetic tree constructed based on the nucleotide sequences of the polymerase chain reaction products amplified using the primer set PBL1v2040/PCRc154 for the B component. Tree was generated using PAUP program. A single most parsimonious tree was predicted by a heuristic search with stepwise addition, random branch-swapping, and treebisection-reconnection options (500 replications for bootstrapping). Bootstrap indices are shown at each node. Scale bar references branch length as frequency of changes per site. 
four groups of distinct begomovirus sequences (Tables 2, 4, and 5; Fig. 2). The individual begomovirus sequences remained in the same group regardless of the analysis. All four groups appear to be New World in origin. The diversity of begomovirus sequences found in this study is noteworthy. Evidence for four distinct begomoviruses plus several sequence variations of these were found in just 12 samples.

Analysis of the partial sequence of the A and $\mathrm{B}$ components from group 1 and 2 suggests that these begomoviruses are closely related to ToVEV, PYMV-VE[tom], and PYMV-VE (Tables 4 and 6; Figs. 2 and 3), which were reported previously in Venezuela $(9,11,19)$. PYMV-VE and ToVEV were first reported in Venezuela in tomato samples from Aragua, and PYMV-VE-[tom] was first reported in tomato growing areas in Monagas, Guárico, and Portuguesa $(9,11,18)$. This suggests that the viruses represented by these partial sequences are established in Venezuela. This study found that PYMVVE and PYMV-VE-[tom] are widely distributed within the Andean states. ToVEV was found in two Andean states (Trujillo and Mérida). The Andean states are separated from the states of Aragua, Monagas, Guárico, and Portuguesa by more than 370 $\mathrm{km}$. It was not expected that the Andean states would share some of the same begomoviruses with such distantly located tomato production regions. The dissemination of these begomoviruses among states might have occurred due to the movement of B. tabaci biotype B or more likely by the movement of virus infected or whitefly infested plants.

Analysis of the PCR products also suggests that there are two unique and uncharacterized begomoviruses present in samples from Trujillo and Mérida states (groups 3 and 4). Only the full-length genome sequences of the A component are considered for comparative analysis, and an NSI of less than $90 \%$ has been proposed to demarcate begomovirus species. Since recombination events have been shown in this genus, partial sequences are not sufficient to distinguish new species (10). Stud- ies are in progress to obtain complete sequences of the genomes of begomoviruses from appropriate samples to determine if they are indeed new species.

This study has indicated the possible presence of four begomoviruses in tomato in the three Andean states of Venezuela. Two of these are considered new species of begomoviruses based on the analyses of their complete genomes (GenBank accession no. AY508991 and AY508992; and AY508993 and AY508994) In addition, a high percentage of samples collected from tomato fields was positive for the presence of at least one begomovirus. These data suggest that begomoviruses may be a larger concern for the Venezuelan tomato industry than was previously believed.

\section{ACKNOWLEDGMENTS}

This research was supported by the Florida Agricultural Experiment Station. This manuscript was approved for publication as Florida Agricultural Experiment Station Journal Series no. R-10734.

\section{LITERATURE CITED}

1. Anzola, D., and Lastra, R. 1978. Protección de semilleros de tomate y su relación con la incidencia del virus mosaico amarillo del tomate. Agron. Trop. 28:473-482.

2. Anzola, D., and Lastra, R. 1985. Whiteflies population and its impact on the incidence of Tomato yellow mosaic virus in Venezuela. Phytopathol. Z. 112:363-366.

3. Argüello-Astorga, G. R., Guevara-Gonzáles, R. G., Herrera-Estrella, L. R., and RiveraBustamante, R. F. 1994. Geminivirus replication origins have a group-specific organization of iterative elements: A model for replication. Virology 203:90-100.

4. Argüello-Astorga, G. R., and Ruiz-Medrano, R. 2001. An iteron-related domain is associated to Motif 1 in the replication proteins of geminiviruses: Identification of potential interacting amino acid-base pairs by a comparative approach. Arch. Virol. 146:1465-1485.

5. Arnal, E., Debrot, E., Marcano, R., and Montagne, A. 1993. Fluctuación poblacional de moscas blancas y su relación con el mosaico amarillo del tomate en una localidad de Venezuela. Fitopatol. Venez. 6:21-26.

6. Arnal, E., Debrot, E., Ramos, F., Cermeli, M., Marcano, R., and Montagne, A. 1993. Lista de moscas blancas (Homoptera: Aleyrodidae) y sus plantas hospederas en Venezuela. Fla. Entomol. 76:365-381.

7. Coutts, R. H. A., Coffin, R. S., Roberts, E. J. F., and Hamilton, W. D. O. 1991. The nucleo- tide sequence of the infectious cloned DNA components of Potato yellow mosaic virus. J. Gen. Virol. 72:1515-1520.

8. Debrot, E., and Centeno, F. 1985. Infection natural de la papa en Venezuela con mosaico amarillo del tomate un geminivirus transmitido por moscas blancas. Agron. Trop. 35:125-138.

9. Debrot, E., Herold, F., and Dao, F. 1963. Nota preliminar sobre un "mosaico amarillento" del tomate en Venezuela. Agron. Trop. 13:33-41.

10. Fauquet, C. M., Bisaro, D. M., Briddon, R. W., Brown, J. K., Harrison, B. D., Rybicki, E. P. Stenger, D. C., and Stanley, J. (Study Group Chair). 2003. Revision of taxonomic criteria for species demarcation in the family Geminiviridae, and an updated list of begomovirus species. Arch. Virol. 148:405-421.

11. Guzman, P., Arredondo, C. R., Emmatty, D., Portillo, R. J., and Gilbertson, R. L. 1997. Partial characterization of two whiteflytransmitted geminiviruses infecting tomatoes in Venezuela. Plant Dis. 81:312.

12. Lastra, R., and Uzcategui, R. 1975. Viruses affecting tomatoes in Venezuela. Phytopathol. Z. 84:253-258.

13. Laufs, J., Traut, W., Heyraud, F., Matzeit, V., Rogers, S. G., Schell, J., and Gronenborn, B. 1995. In vitro cleavage and joining at the viral origin of replication by the replication initiator protein of Tomato yellow leaf curl virus. Proc. Natl. Acad. Sci. USA 92:3879-3883.

14. Morales, F., Lastra, R., Uzcategui, R., and Calvert, L. 2001. Potato yellow mosaic virus: A synonym of Tomato yellow mosaic virus. Arch. Virol. 146:2249-2253.

15. Nava, A., Ochoa, F., Trujillo, G., Geraud, F Hernández, L., Lastra, R., and Rivas, G. 1996. Detección de virus en zonas productoras de tomate (Lycopersicon esculentum Mill) en Venezuela. I Estados Aragua y Zulia. Rev. Fac. Agron. (LUZ). 13:285-292.

16. Nava, A., Trujillo, G., Chirinos, D., and Rivero, G. 1997. Detección de virus en zonas productoras de tomate (Lycopersicon esculentum Mill) en Venezuela. II Estados andinos (Mérida, Táchira y Trujillo). Rev. Fac. Agron. (LUZ). 14:611-624

17. Rath, P., Rajaseger, G., Goh, C. J., and Kumar, P. P. 1998. Phylogenetic analysis of Dipterocarps using Random Amplified Polymorphic DNA markers. Ann. Bot. 82:61-65.

18. Roberts, E. J. F., Buck, K. W., and Coutts, R. H. A. 1986. A new geminivirus infecting potatoes in Venezuela. Plant Dis. 70:603.

19. Roberts, E. J. F., Buck, K. W., and Coutts, R H. A. 1988. Characterization of Potato yellow mosaic virus as a geminivirus with a bipartite genome. Intervirology 29:162-169.

20. Rojas, M. R., Gilbertson, R. L., Russell, D. R., and Maxwell, D. P. 1993. Use of degenerate primers in the polymerase chain reaction to detect whitefly-transmitted geminiviruses. Plant Dis. 77:340-347. 